\title{
Biodiesel Production from Rubber Seed Oil via Esterification Process
}

\author{
W. Widayat* and S. Suherman \\ Chemical Engineering Department, Faculty of Engineering, Diponegoro University, \\ Jl.Prof Sudharto,SH-Tembalang, Semarang INDONESIA
}

\section{Article history:}

Received April 30, 2012 Received in revised form May 16, 2012 Accepted May 22, 2012 Available online

\begin{abstract}
One promise source of alternative energy is biodiesel from rubber seed oil, because the raw materials available in plentiful quantities and can be renewed. In addition, the rubber seed is still lack of utilization, and Indonesia is one of the largest rubbers producing country in the world. The objective of this research is to studied on biodiesel production by esterification process. Parameters used in this study are the ratio of catalyst and temperature and its influence on the characteristics of the resulting biodiesel product. Characterization of rubber seed include acid content number analysis, saponification numbers, density, viscosity, iodine number, type of free fatty acids and triglyceride oils. The results of analysis showed that rubber seed oil content obtained is $50.5 \%$. The results of the GCMS analysis showed that a free fatty acid level in rubber seed is very high. Conversion into bio-diesel oil is obtained by at most $59.91 \%$ and lowest $48.24 \%$.
\end{abstract}

Keywords: conversion, density, free fatty acid levels, rubber seed oil, viscosity

\section{Introduction}

Fossil fuel is a source of energy that cannot be renewed. The increase in fossil fuel prices in Indonesia encourages savings and research efforts to find an alternate fuel resource. In 2015, Indonesia is predicted to be a net importer of petroleum management (netimporter). Therefore, an alternative fuel is needed to overcome the internal demand. Vegetable oils such as soybean oil, palm oil and olive oil can be used as renewable fuel, especially diesel fuel (biodiesel). Biodiesel from vegetable oil has the advantages such as environmentally friendly, renewable and the emissions are relatively clean. The government has started to support the activities in finding new resource for fuel such as biodiesel, bioethanol, bio-oil, bio-gas, fuel from natural gas. For biodiesel program, the Government of Indonesia has developed a conversion process of vegetable oils such as castor oil, rubber, CPO to biodiesel [1].

Vegetable oil can be obtained from seeds of plants. Various vegetable oil has developed as a raw material in production of biodiesel, such as is palm oil [2, 3], castor oil and rubber seed oil $[4,5]$. Currently, rubber seed is a waste and lack of utilization. The potential of rubber seed oil in Indonesia is abundant. The total area of rubber plantations in Indonesia reaches over 3 million hectares, the largest in the world. In Central Java, there are rubber plantations $23,515.32$ ha with production $19,971.13$ tons / year [6]. Rubber plant is one of the producers of vegetable oils obtained from seeds, with $37.5 \%$ yield of oil. Therefore, rubber seed selected as raw materials in this study because it has not been utilized and there are plentiful numbers [7].

The common process of biodiesel production is esterification and transesterification reactions. In the esterification reaction the free fatty acid should be low, ie about $0.5 \%$ weight. If not met, then large base catalyst is required, and biodiesel products will be mixed with soap to form emulsion. Then the separation process of biodiesel from glycerol is more difficult and yield lower [3, 8]. Garpen and Canakei (2000) was produce of biodiesel from palm oil that contains high free fatty acids (20-40\%), so It has been carried out by esterification of free fatty acids with acid catalyst, then transesterification with alkaline catalysts [9].

Esterification process is a method to produce ester (RCOOR') by reacting an acid compound and alcohol

\footnotetext{
Corresponding author. Tel: +62-24-7460058

E-mail : yayat_99@yahoo.com
} 
with eliminate a water in the reaction $[2,5,9,12]$. The acid catalyst is often used is a strong mineral acid, such as hydrochloric acid, and sulfuric acid. The objective of this research is to studied on biodiesel production by esterification process and study of kinetic reaction of esterification of rubber seed oil.

\section{Materials and Methods}

\subsection{Materials}

Rubber seeds obtained from PT. Perkebunan Nusantara IX (Sukomangli, Kendal). Rubber seeds cleaned from skin. Seeds that have clean, treated by cooking with steamed, then pressed with mechanical press. The oil is measured in volume and tested characteristics. Characterization includes the analysis of rubber seed acid number, density, viscosity, free fatty acid levels and triglyceride[9,10]. Types of free fatty acids and triglyceride oils analyzed by means of GCMS. The catalyst used was KOH (MERCK) and methanol as a reactant to industrial specifications.

\subsection{Methods}

The ratio of catalyst to methanol (vol) and temperature was studied in biodiesel production. Experimental design using 2-level factorial design is shown in Table 1. Variables used are as follows: dependend variable: volume of rubber seed oil 430 grams, pressure $1 \mathrm{~atm}$, acid concentration $1 \mathrm{M}$; and independent variable: temperature $\left({ }^{\circ} \mathrm{C}\right): 60(-) 80(+)$, ratio methanol to catalyst : $2: 1(-) ; 4: 1(+)(\mathrm{v} / \mathrm{v})$.

Tabel 1

Two level factorial design experiment in producing biodiesel

\begin{tabular}{ccc}
\hline \multirow{2}{*}{ Run } & \multicolumn{2}{c}{ Variable } \\
\cline { 2 - 3 } & $\mathbf{X}_{\mathbf{1}}$ & $\mathbf{X}_{\mathbf{2}}$ \\
\hline 1 & + & - \\
2 & - & - \\
3 & + & + \\
4 & - & + \\
5 & 0 & 0 \\
6 & 0 & 0 \\
\hline Description: +: Upper limits, -: Lower limit, 0: the value of the $\mathrm{X}_{1}:$ code for temperature $\left({ }^{\circ} \mathrm{C}\right)$
\end{tabular}

$60(-) ; 80(+), \mathrm{X}_{2}$ : code for ratio of methanol/catalyst: $2 ; 1(-): 4: 1(+)(\mathrm{v} / \mathrm{v})$

$\mathrm{X}_{1}=\frac{\mathrm{T}-70}{10}$

$\mathrm{X}_{2}=\frac{\text { Volume methanol-3 }}{1}$

Esterification process carried in a three neck bottle that equipped with a cooler. The heating process using heaters water and stirring was with stirrer magnetic. Esterification process is carried out with methanol and acid catalyst (i.e. sulphuric acid $1 \mathrm{M}$ ). Free fatty acid content was analyzed every 5 minutes [11].

\section{Results and Discussion}

\subsection{Characteristics of the raw material of rubber seed}

Table 2 shows the results of analysis of rubber seeds. These results indicate that rubber seed oil has the potential to be taken up to $50.5 \%$. These results are in accordance with Table 2, where the content of rubber seed oil in approximately $40-50 \%$. Oil is still trapped in the rubber seed meat must be processed to obtain rubber seed oil. The results was similar with literature $[5,7]$.

Tabel 2

Characteristics of the raw materials of rubber seed

\begin{tabular}{cc}
\hline Variable & Value \\
\hline Moisture & 16.57 \\
Ash & - \\
Oil & 50.5 \\
\hline
\end{tabular}

\subsection{Characteristics of the rubber seed oil}

Table 3 shows that the free fatty acid levels in seeds of rubber is very high (almost 17\%). This free fatty acid can be converted into methyl ester (biodiesel) via esterification. Esterification is process for converting free fatty acids into methyl esters. The process of biodiesel production by esterification process, requires free fatty acid content is low $(<0.5 \%)[2,8]$. The type of free fatty acids were analyzed using GCMS (Gas Chromatography Mass Spectroscopy). The composition of fatty acids consisting of palmitic acid, linoleic acid, oleic acid, as well as triglyceride oils. The largest component of free fatty acids is linoleic acid approximately $14.34 \%$ or approximately $86.53 \%$ of the free fatty acid total in the oil.

Tabel 3

Characteristics of rubber seed oil

\begin{tabular}{cc}
\hline Variable & Result \\
\hline Free fatty acid (\%) & $10,39-16,48$ \\
Density (gr/ml) & $0,903-0,93$ \\
Viscosity (cp) & $0,404-0,774$ \\
Palmitat acid (\%) & 0,75 \\
Linoleat acid (\%) & 14,34 \\
\hline
\end{tabular}

Figure 1 shows the analysis result with GCMS, with the residence time is shown in Table 4. Largest peak obtained at a residence time of 20.711 for linoleic acid. Number of free fatty acids is calculated by multiplying the percentage of area with content of oil free fatty acid (i.e. $16.57 \%$ ). 


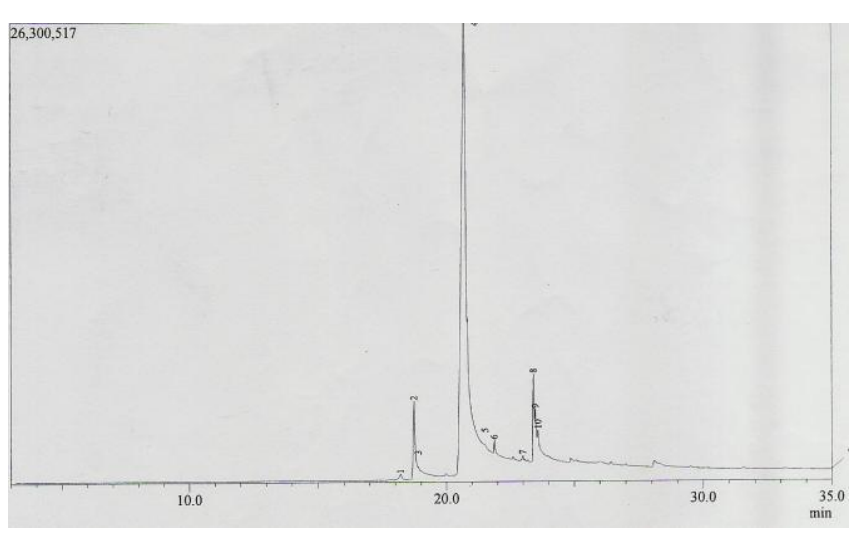

Fig. 1 Chromatogram of free fatty oil analysis

Tabel 4

Summary of GCMS analysis results of free fatty acids in oils

\begin{tabular}{cccc}
\hline No. & Residence time & Percent (\%) & Acid \\
\hline 1 & 18,1999 & 0,13 & \\
2 & 18,726 & 4,51 & Palmitat \\
3 & 18,883 & 0,15 & \\
4 & 20,711 & 86,53 & Linoleat \\
5 & 21,508 & 0,06 & Dekanoat \\
6 & 21,864 & 0,53 & \\
7 & 22,993 & 0,14 & Linoleat \\
8 & 23,411 & 3,57 & Dekanoat \\
9 & 23,478 & 2,28 & \\
10 & 23,580 & 2,11 & \\
\hline
\end{tabular}

\subsection{Estherification Process}

Figure 2 shows the graph of free fatty acid concentration versus time. Reaction time stoped after the analysis showed that changes in free fatty acid levels fixed (constant). This condition indicates that the reaction has reached equilibrium conditions. The results indicate a difference in operating time for each process of esterification. Run $1\left(80^{\circ} \mathrm{C}\right.$, the ratio of free fatty acids with a catalytic $1: 2$ ) obtained operating time approximately 45 minutes. Run $4\left(60^{\circ} \mathrm{C}\right.$, the ratio of free fatty acids with a catalytic $1: 4$ ) obtained operating time approximately 75 minutes. Both variables seem to have a similar effect.

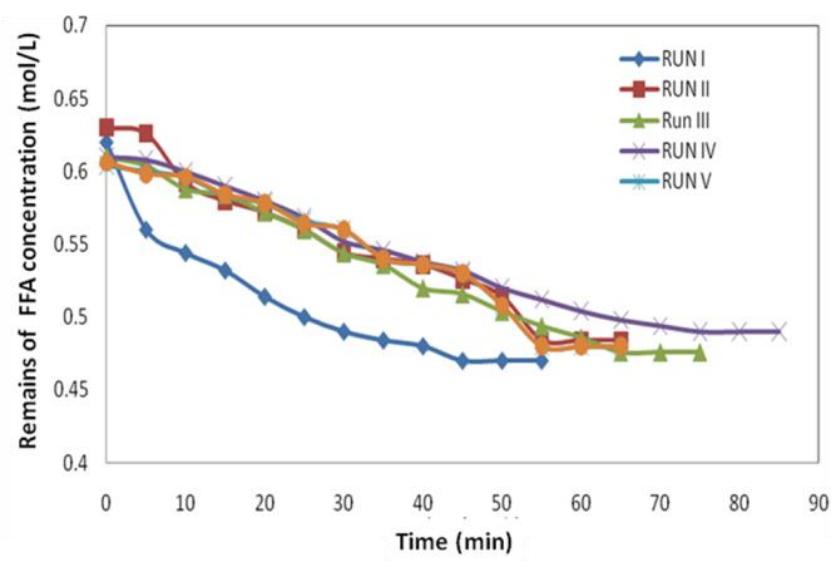

Fig. 2 Remaining concentration of free fatty acids vs operating time
Further analysis is the conversion can be achieved in the esterification process. This data is then analyzed with statistics to know the influential variables and the results shown in Table 5, Figure 3 and Figure 4. In the esterification process, each 1 mole of free fatty acids will react with 1 mole of methanol to form methyl esters. Conversion obtained was small enough, this occurs because esterification process is the reaction reversible, so that the conversion is achieved has equilibrium conditions. In other words, the conversion can not be increased again. Conversion obtained at most for the lowest $59.91 \%$ and $48.24 \%$ (see Table 5). In esterification reaction was used $\mathrm{H}_{2} \mathrm{SO}_{4} 1 \mathrm{M}$ as catalyst, so in this solution must be added water. The presence of water in the reactants can reduce the rate of reaction. Water will be released during the esterification reaction takes place. Thus the total mass of water in the reactants into the reaction will be more difficult in the direction of the product. This led to the biodiesel conversion reaction is too small.

Tabel 5

Analysis results of esterification process

\begin{tabular}{cccc}
\hline \multirow{2}{*}{ Run } & \multicolumn{2}{c}{ Variable } & $\begin{array}{c}\text { Conversion producing } \\
\text { methyl ester (\%) }\end{array}$ \\
\cline { 2 - 3 } & $\mathbf{X}_{\mathbf{1}}$ & $\mathbf{X}_{\mathbf{2}}$ & 59,91 \\
2 & +1 & -1 & 58,32 \\
3 & -1 & -1 & 49,05 \\
4 & +1 & +1 & 48,24 \\
5 & -1 & +1 & 49,75 \\
6 & 0 & 0 & 50,55 \\
\hline
\end{tabular}

Figure 3 is a Pareto chart for each variable. Variable 2 is the value of the coefficient of effect parameters $X_{2}$, and variable 1 is the value of the coefficient of effect parameters $X_{1}$, and 1 by 2 is value of the variable effects interaction between $X_{1}$ and $X_{2}$. From the Pareto chart shows that the variable ratio of the volume of free fatty acids with catalyst volume more powerful compared with the variable temperature. Catalyst will accelerate the reaction rate, so conversion of the esterification process to increase.

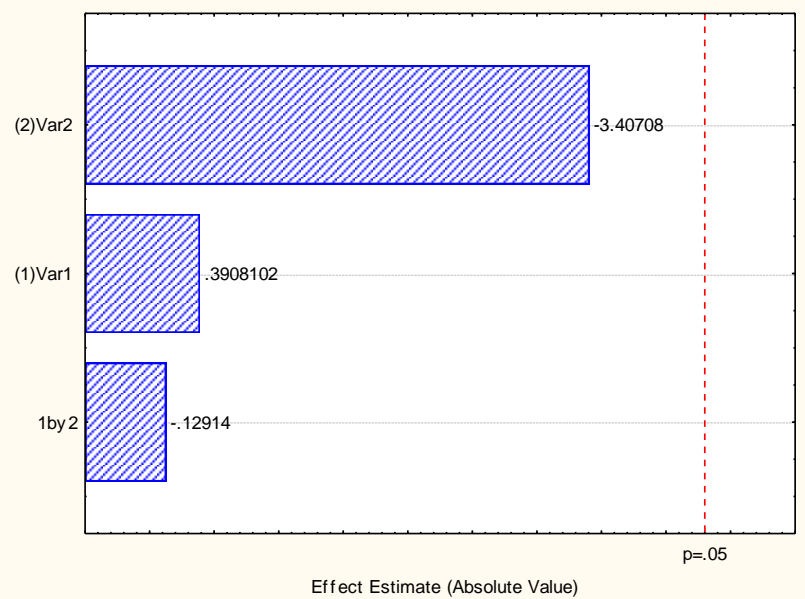

Fig. 3 Pareto graph 
Variable coefficient value $X_{2}$ value (-) negative that means decrease of $X_{2}$ can be obtained increase of biodiesel conversion. The value effect of $\mathrm{X}_{1}(+)$ positive that means the higher the conversion temperature obtained biodiesel conversion higher. This is reinforced with probability graph (Fig. 4). The value of $\mathrm{X}_{2}$ variable effects farthest from the other variables. This means that the second variable $\left(\mathrm{X}_{2}\right)$ is more influential than the $\mathrm{X}_{1}$.

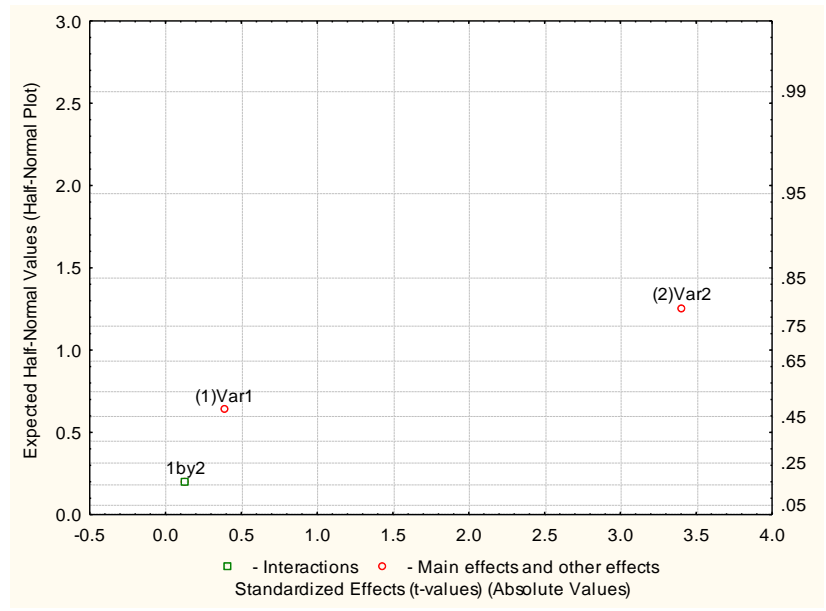

Fig. 4 Probability graph of variables

Modeling mathematic for statistic analysis like as presented in equation 3 . The parameter value in this equation was similar with statistic analysis.

$$
Y=52.637+1.2 x_{1}-10.47 x_{2}-0.39 x_{1} x_{2}
$$

\section{Conclusion}

Characteristics of rubber seed is $16.57 \%$ of water content and $50.5 \%$ of oil content. The composition of free fatty acids includes $14.34 \%$ of linoleic acid. The time needed for the esterification vary from 50-70 minutes. Variable volume ratio of free fatty acids with catalyst is more powerful than temperature variable.

\section{References}

[1] Anonymous, 2005, Buku Putih Program Pembangunan Iptek Bidang Ketersediaan Dan Pemanfaatan Sumber Energi Baru Dan Terbarukan 2005-2009.

[2] Rasidi, 2005, Kinetika Esterifikasi Asam Lemak Bebas dalam Minyak Sawit untuk pembuatan biodiesel, Prosiding Seminar Nasional Teknik Kimia "Kejuangan", UPN Veteran Yogyakarta.

[3] Kalam, M.A., and Masjuki, H.H., 2002, "Biodiesel from palmoil-an analysis of itsproperties and potential," Biomass and Bioenergy 23 p.471-479.

[4] Palupi, S dan D. D., Anggoro, 2007, Transesterifikasi Minyak Biji Karet Dengan Katalis $\mathrm{NaOH}$ dan $\mathrm{KOH}$, Prosiding Seminar Masyarakat Katalis Indonesia Society (MKICS) Semarang.

[5] Ramandhas, A.S. S. Jayaraj, and C. Muraleedharan, 2005, Biodiesel production from high FFA rubber seed oil, Fuel $84 \mathrm{pp}$ 335-340.

[6] Plantation Office of Central Java Province, 2003.

[7] Heyne, K, (1987), "Tumbuhan Berguna Indonesia II" , Badan Litbag Kehutanan, Jakarta, hal. 1186-1187.

[8] Krawczyk, T., 1996 Biodiesel-Alternative fuel makes inroad but hurdles remain, INFORM 7, p.801-829.

[9] Garpen, J.V., and Canakei M., 2000, " Biodiesel Production from Oils and Fats with High Free Fatty Acids", Am. Soc. Of Agricultural Eng., Vol. 44 : 1429-1436.

[10] Hamilton, R.J. and Rossel, J.B., 1986, Analysis of Oils and Fats, 1st edition, Elsevier Applied Science Publisher Ltd.

[11] Paquout, C., 1979. Standard Methods for The Analysis of Fats and Derivatives, 6th edition, Pergamon Press, New York.

[12] Freedman BEHP, Mounts TL, 1984, Variables affecting the yields of fatty ester from transesterified vegetable oils JAOCS. 